\title{
Embarrassment during Retail Encounters: Contribution to the Theory of Rapport
}

\author{
Iracema Medeiros d'Abreu ${ }^{1}$, Irene Raguenet Troccoli ${ }^{2}$, *, João Felipe Sauerbronn ${ }^{3}$ and \\ Paulo Roberto da Costa Vieira ${ }^{4}$ \\ ${ }^{1,2,4}$ Universidade Estácio de Sá, Rio de Janeiro, Brazil \\ ${ }^{3}$ Universidade do Grande Rio, Rio de Janeiro, Brazil
}

\begin{abstract}
.
In retail settings, rapport is the perception of customers that their interaction with frontline employees (FLEs) is pleasant, building a personal connection between both parties. During retail encounters, it is possible for embarrassment to arise, which normally can be identified by nonverbal interpersonal communication, consisting of physical evidence like eye movements, posture and blushing. Embarrassment can have negative effects on the behaviors of customers, so it is good marketing policy to make all efforts to alleviate this feeling. In particular, pharmacies and drugstores are propitious for embarrassing situations and, for this reason, the study of embarrassment is particularly interesting in the case of FLEs who work at these premises. This qualitative study at drugstores in a Brazilian city examines how nonverbal interpersonal communication practiced by FLEs can create rapport during encounters with embarrassed retail consumers. Results show six ways by which this can happen, evidencing complex behavioral patterns among FLEs, although without emphasis on a specific communication style. Despite showing verbal and nonverbal elements, the two were not always associated in FLEs' behavior, indicating that rapport can be used to reduce embarrassment. Contribution to the theory of rapport comes from challenging the preconception that its identified categories are mutually exclusive and comprehensive

Keywords: embarrassment; rapport; retail encounters; nonverbal interpersonal communication; critical incident technique
\end{abstract}

\section{Introduction}

In retail settings, rapport is the perception of customers that their interaction with frontline employees (FLEs) is pleasant, building a personal connection between both parties (Gremler \& Gwinner, 2008). During retail encounters, it is possible for embarrassment to arise (Wu \& Mattila, 2013), which normally can be identified by nonverbal interpersonal communication (NVIC), consisting of physical evidence like eye movements, posture and blushing (Keltner \& Buswell, 1997). Embarrassment can have negative effects on the behaviors of customers (Wu \& Mattila, 2013), so it is good marketing policy to make all efforts to alleviate this feeling. In particular, pharmacies and drugstores are propitious for embarrassing situations because, there, consumers "can buy a series of products that can cause embarrassment, such as condoms, pregnancy tests and the morning-after pill, among others" (Isabella, Barros \& Mazon, 2015, p. 627). For this reason, the study of embarrassment is particularly interesting in the case of FLEs who work at these premises, since, although they frequently face 


\section{$10^{\text {th }}$ International Conference on Modern Research in MANAGEMENT, ECONOMICS and ACCOUNTING}

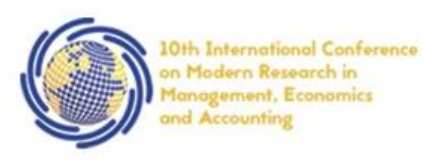

\section{0-22 March, 2020}

Berlin, GERMANY

situations where customers are embarrassed while buying drugs or personal care products, they normally do not receive formal training on how to deal with these situations (Instituto Racine, 2018). This can prompt them to voluntarily act as they see fit. This article describes how NVIC can create rapport with customers, and hence reduce embarrassment during interaction at drugstores. After this brief introduction, a theoretical framework is presented, followed by methodological aspects, results, discussion and conclusion.

\section{Theoretical Framework}

In a retail service relationship, rapport is a customer perception that his/her interaction with FLEs is pleasant, sealed by a personal connection (Gremler \& Gwinner, 2000). Gremler and Gwinner (2008) proposed a typology with five main categories and their respective subcategories of behaviors for creation of rapport in commercial contexts, which partially inspired our study: 1) Uncommonly attentive behavior: the employee, as perceived by the customer, acts uncommonly, with three subcategories: 1.1) atypical actions (e.g., doing something totally outside the script to meet a need of the customer); 1.2) personal recognition (e.g., the employee recognizes the customer by name); and 1.3) intense personal interest (e.g., the employee shows interest in the customer as a person); 2) Common grounding behavior: the FLE seeks to discover something in common with the customer, with two subcategories: 2.1) identification of mutual interests (e.g., hobbies); and 2.2) identification of other similarities (e.g., same ages); 3) Courteous behavior: a bond is rapidly formed between the FLE and the customer, with three subcategories: 3.1) civility (e.g., treating customers politely, without evident differences based on how much is spent); 3.2) honesty (e.g., identifying the real advantages of a product); and 3.3) empathy (e.g., ability to see things from the customer's point of view, based on understanding his/her priorities); 4) Connecting behavior: the employee explicitly tries to develop a tie with the customer, with three subcategories: 4.1) humor (e.g., telling a joke or making the customer laugh); 4.2) pleasant conversations (e.g., about weather forecasts); and 4.3) friendly interaction (e.g., the employee's friendliness when interacting with the customer is perceived as more intense than normal in the given context); 5) Information sharing behavior: the employee tries to share information with or collect information from the customer, to better understand and more effectively meet needs, with three subcategories: 5.1) giving advice (e.g., employee making suggestions to the customer about the product or service); 5.2) imparting knowledge (e.g., sharing the employee's own experience and knowledge about a topic); and 5.3) asking questions (e.g., employee asking specific questions to find out what the customer really is looking for at the store).

Research about rapport in commercial contexts has shown that people can judge strangers intuitively and precisely based on viewing their face or on observing their behavior for very brief periods (Willis \& Todorov, 2006). Expressive similarity is the similarity between nonverbally expressed emotions of FLEs and customers' receptivity to emotions expressed nonverbally (Lim, Lee \& Foo, 2017), a phenomenon that causes positive first impressions (Human \& Biesanz, 2011). Consequently, the impressions of customers about the characteristics of FLEs - such as competence and professionalism - will be more favorable when there is a higher level of expressive similarity. And when customers perceive higher levels of expressive similarity regarding a service employee, and thus experience strong rapport, they will more likely evaluate the service experience positively. 


\section{$10^{\text {th }}$ International Conference on Modern Research in MANAGEMENT, ECONOMICS and ACCOUNTING}

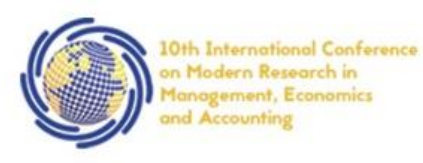

\section{0-22 March, $2020 \quad$ Berlin, GERMANY}

One of the most common opportunities for rapport in the service sector occur in personal encounters, especially via NVIC. NVIC refers to the process by which, while interacting, individuals use resources other than spoken language, such as body language or feelings, which are perceived and interpreted by the other person while interacting, conveying the emotional state, personality or behavioral intentions of an individual (Hall, Horgan \& Murphy, 2005). Sharing of information between a service provider and a customer should be carried out empathetically and affectively for communication to be effective (Park et al., 2012). This is true to all commercial relations, but particularly important during services rendering, due to intangibility and simultaneity (Zeithaml, Bitner \& Gremler, 2014), and to the strong role that emotions play for good outcomes (Gremler et al., 2017). Both verbal and nonverbal communication affect customers by involving a critical interpersonal process that consists of a continuous cycle of exchanging information (Schramm, 1954). Customers also simultaneously influence the nonverbal responses of service providers (Sundaram \& Webster, 2000).

In terms of NVIC typologies, due to the emphasis of this approach on the impact of the NVIC of service providers on the satisfaction of customers, that of Sundaram and Webster (2000) stands out, formed by four aspects: a) paralanguage: tone, intensity, vocal amplitude, fluency or pauses, used during transmission of a message as hints to identify the real emotional state of the speaker (Sidtis \& Kreiman, 2012); b) kinetics: body movements, posture, eye contact, head inclination, hand movements and facial expressions (Newman et al., 2016); c) personal appearance of the service provider: personal hygiene, clothing style, state of conservation of uniforms (Sundaram \& Webster, 2000); and d) proxemic communication: nonverbal communication that involves the unconscious structure of people in space, such as the distance between people when engaging in daily transactions (Hall, 1963).

\section{Method}

Secondary research for this qualitative-descriptive research (Creswell, 2010) came from the literature (Creswell, 2010), while field research took place in 18 drugstores in Teresópolis, a small city $100 \mathrm{~km}$ from the capital Rio de Janeiro. Primary data were obtained by means of the critical incident technique (CIT) (Flanagan, 1954), as well as of in-depth interviews and of non-participant observation (Farmer et al., 2006), assuring triangulation. Two types of subjects anonymously participated in the study, all possibly involved in situations when embarrassment could happen: 1) "Subjects": 57 FLEs (17 women and 40 men) submitted to the CIT during eight field visits, including 35 sales clerks, 12 pharmacists and three managers, with ages ranging from 20 to 50 years old. No specific filter was used, assuming that any of these respondents may interact with embarrassed customers. Their usable responses indicated 51 critical incidents; 2) "Interviewees": eight drugstore managers (excluding those taking part in the CIT) submitted to exploratory in-depth interviews. This helped elucidate certain parts of the CIT, apart from learning whether there was a store policy for multi-gender staff, and whether management was open to the creation or adoption of specific staff training aimed at dealing with embarrassed customers. The whole content of the interviews was recorded and transcribed.

All research subjects verbally reported situations of embarrassment by customers during encounters, enabling investigation of the possible spontaneous use of NVIC by the FLEs. The 


\title{
$10^{\text {th }}$ International Conference on Modern Research in
} MANAGEMENT, ECONOMICS and ACCOUNTING

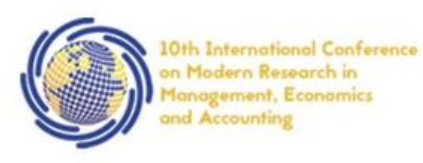

\section{0-22 March, 2020}

\author{
Berlin, GERMANY
}

main products causing embarrassment were those associated with sexual behavior, especially the day-after pill and remedies for erectile dysfunction. As for the content of the interviews, it was interpretively analyzed (McCracken, 1988).

\section{Results and Discussion}

\subsection{Results of the first CIT application}

Categories were built to allow identification not only of the main behavior, but also of the predominant combinations specific to rapport building with embarrassed customers. Thus, 1) To serve as a base, we selected the five categories and respective subcategories of behaviors that were identified as possible facilitators of rapport (Table 1), which were subsequently transferred to the first column of Table 3; 2) Based on the content analysis of primary data from the CIT, we identified which behaviors were used by the FLEs in drugstores to facilitate rapport in embarrassing situations, which were subsequently transferred to the third column of Table 3; and 3) These behaviors were associated with some subcategories (see $2^{\text {nd }}$ column of Table 3 ) among all the subcategories listed in the first column of that table, excluding seven categories of Gremler and Gwinner (2008) (see $2^{\text {nd }}$ column of Table 1) that, according to presuppositions based on good sense, did not pertain to the theme of embarrassment. 4) In order to create the categories used in this study, we identified the emphasis of these behaviors (see $4^{\text {th }}$ column in Table 2), based on the selection of behaviors aimed at facilitating rapport in drugstores, associated with the subcategories considered pertinent to the theme of rapport in embarrassing situations. This emphasis fits in three types of behavior, two of them identified in the literature review (verbal and nonverbal); the third one was a behavior observed during the field research but not yet identified in the literature, which constitutes the contribution of this study to the theory of rapport: 4.1) The field research identified complex behavioral patterns that can facilitate rapport in embarrassing situations to which drugstores are prone, without emphasis on specific communication. Despite having verbal and nonverbal elements, its interpretation based on analysis of the primary evidence indicated it was not simply associated with the sum of the two. In this category - whose configurative complexity led us to label it multifaceted behavior - we noted a set of elements that could be associated with a specific behavior, with nomenclature taken as common for being habitually used when interacting with customers. During the first conduction of the CIT, two subcategories were identified: 4.1.1) warm treatment, which includes a complex combination of simultaneous actions such as welcoming tone of voice, happy physiognomy, positioning near the customer, making suggestions and supplying information; and 4.1.2) professionally distant treatment, with a dual association: a) with some verbal elements, such as connection through information and questions; and $b$ ) with characteristically nonverbal elements, but not necessarily included in the subcategories selected in isolation as nonverbal, such as more reserved physiognomy (without a specific category), low tone of voice (paralanguage) and distance (proxemics); 5) Finally, we created 11 categories with nomenclature tailored for rapport in embarrassing situations associated with each of the three categories (see 5th column of Table 2).

Table 1: Categories of Gremler and Gwinner (2008) from which subcategories were removed, and the reason for these exclusions 


\section{$10^{\text {th }}$ International Conference on Modern Research in MANAGEMENT, ECONOMICS and ACCOUNTING}

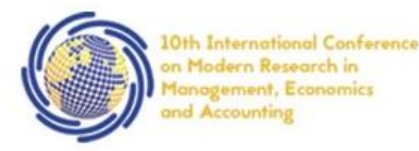

\begin{tabular}{|c|c|c|}
\hline $\begin{array}{c}\text { Category of Gremler and } \\
\text { Gwinner (2008) from } \\
\text { which one or more } \\
\text { subcategories were } \\
\text { excluded }\end{array}$ & $\begin{array}{l}\text { Subcategory } \\
\text { excluded }\end{array}$ & Reason for exclusion \\
\hline $\begin{array}{l}\text { Uncommonly attentive } \\
\text { behavior }\end{array}$ & $\begin{array}{l}\text { Intense personal } \\
\text { interest }\end{array}$ & $\begin{array}{l}\text { Since this approach is very incisive, it would be counter- } \\
\text { productive for embarrassed customers. }\end{array}$ \\
\hline $\begin{array}{l}\text { Common grounding } \\
\text { behavior or common base }\end{array}$ & $\begin{array}{l}\text { Identification of } \\
\text { mutual interests }\end{array}$ & $\begin{array}{l}\text { This type of approach does not apply to embarrassing } \\
\text { situations. }\end{array}$ \\
\hline \multirow[b]{2}{*}{ Courteous behavior } & Honesty & Embarrassed customers do not need opinions from the FLEs \\
\hline & Empathy & $\begin{array}{l}\text { To act atypically (first subcategory of Table } 3 \text { ), it is } \\
\text { necessary to have empathy. Therefore, to avoid repetition, } \\
\text { this was excluded. }\end{array}$ \\
\hline \multirow[b]{2}{*}{ Connecting behavior } & Humor & $\begin{array}{l}\text { In a situation of embarrassment, no type of humor is } \\
\text { welcome. }\end{array}$ \\
\hline & $\begin{array}{c}\text { Pleasant } \\
\text { conversation }\end{array}$ & $\begin{array}{l}\text { Embarrassed customers do not want verbal interaction } \\
\text { beyond the minimum necessary, because they want to make } \\
\text { the purchase as quickly as possible. }\end{array}$ \\
\hline $\begin{array}{l}\text { Information sharing } \\
\text { behavior }\end{array}$ & Giving advice & Sales clerks are not allowed to recommend medicines. \\
\hline
\end{tabular}

Table 2 - Elements considered in the building up of the categories and subcategories identified in the field research

\begin{tabular}{|c|c|c|c|c|}
\hline \multicolumn{2}{|c|}{$\begin{array}{l}\text { Categories of behavior that facilitate rapport } \\
\text { verified by Gremler \& Gwinner (2008) and } \\
\text { Nickels, Everett \& Klein (1983) }\end{array}$} & \multirow[b]{2}{*}{$\begin{array}{c}\text { Behaviors } \\
\text { identified as } \\
\text { facilitating rapport } \\
\text { in embarrassing } \\
\text { situations }\end{array}$} & \multirow{2}{*}{$\begin{array}{c}\text { Categories } \\
\text { created in this } \\
\text { study for rapport } \\
\text { in embarrassing } \\
\text { situations, } \\
\text { according to the } \\
\text { emphasis of the } \\
\text { behavior }\end{array}$} & \multirow{2}{*}{$\begin{array}{l}\text { Subcategories } \\
\text { of rapport in } \\
\text { embarrassing } \\
\text { situations: how } \\
\text { connection is } \\
\text { enabled }\end{array}$} \\
\hline $\begin{array}{l}\text { All the } \\
\text { categories verified } \\
\text { and the respective } \\
\text { subcategories }\end{array}$ & $\begin{array}{c}\text { Subcategories } \\
\text { selected applicable to } \\
\text { the type of rapport } \\
\text { behavior in } \\
\text { embarrassing } \\
\text { situations }\end{array}$ & & & \\
\hline \multirow{2}{*}{\begin{tabular}{l}
\multicolumn{1}{c}{ Uncommonly } \\
attentive behavior \\
(Gremler \& \\
Gwinner, 2008): \\
Refers to situations \\
where the employee, \\
as perceived by the \\
customer, performs \\
uncommon actions.
\end{tabular}} & \multirow{3}{*}{$\begin{array}{l}\text { Atypical actions: refers } \\
\text { to doing things totally } \\
\text { outside the script to } \\
\text { meet a need of a } \\
\text { particular customer. }\end{array}$} & $\begin{array}{c}\text { Particularly } \\
\text { attentive behavior, } \\
\text { with focus on the } \\
\text { customer, } \\
\text { allowing the FLE } \\
\text { to identify } \\
\text { embarrassment. }\end{array}$ & \multirow{3}{*}{$\begin{array}{l}\text { Behavior with } \\
\text { nonverbal } \\
\text { emphasis }\end{array}$} & $\begin{array}{l}\text { Through } \\
\text { concentrated } \\
\text { attention }\end{array}$ \\
\hline & & $\begin{array}{c}\text { The FLE } \\
\text { adapts the voice to } \\
\text { the same volume } \\
\text { used by the } \\
\text { customer. }\end{array}$ & & $\begin{array}{c}\text { Use of } \\
\text { paralanguage }\end{array}$ \\
\hline $\begin{array}{l}\text { 1. Atypical } \\
\text { actions (broken } \\
\text { down into three } \\
\text { behaviors, as } \\
\text { detailed in the third } \\
\text { column of this table) } \\
\quad 2 . \text { Personal } \\
\text { recognition }\end{array}$ & & $\begin{array}{l}\text { The FLE moves } \\
\text { closer to the } \\
\text { customer, so that } \\
\text { the interaction can } \\
\text { be more discreet } \\
\text { (e.g., leaves the } \\
\text { counter area and } \\
\text { goes to a corner of }\end{array}$ & & $\begin{array}{l}\text { Through } \\
\text { proxemics }\end{array}$ \\
\hline
\end{tabular}


$10^{\text {th }}$ International Conference on Modern Research in

MANAGEMENT, ECONOMICS and ACCOUNTING

\section{0-22 March, 2020 Berlin, GERMANY}

\begin{tabular}{|c|c|c|c|c|}
\hline \multirow{2}{*}{$\begin{array}{l}\text { 3. Intense } \\
\text { personal interest: } \\
\text { excluded from this } \\
\text { analysis (see Table } \\
\text { 1). }\end{array}$} & & the store). & & \\
\hline & $\begin{array}{l}\text { Personal } \\
\text { recognition: Refers to } \\
\text { situations when the } \\
\text { employees recognized } \\
\text { customers by name or } \\
\text { remember specific } \\
\text { information about a } \\
\text { determined customer. }\end{array}$ & $\begin{array}{l}\text { The FLE tries } \\
\text { to stay away from } \\
\text { customers, } \\
\text { knowing they will } \\
\text { be even more } \\
\text { embarrassed when } \\
\text { recognized. } \\
\text { Hence, this } \\
\text { category was used } \\
\text { in its opposite pole } \\
\text { - non-recognition } \\
\text { of the customer - } \\
\text { for the purpose of } \\
\text { anonymity. }\end{array}$ & $\begin{array}{l}\text { Behavior with } \\
\text { nonverbal } \\
\text { emphasis }\end{array}$ & $\begin{array}{l}\text { Through } \\
\text { discretion }\end{array}$ \\
\hline $\begin{array}{l}\text { Common } \\
\text { grounding or } \\
\text { common base } \\
\text { behavior (Gremler } \\
\text { \& Gwinner, 2008): } \\
\text { refers to situations } \\
\text { in which FLEs try to } \\
\text { discover something } \\
\text { they have in } \\
\text { common with the } \\
\text { customer. Formed } \\
\text { by two } \\
\text { subcategories: } \\
\text { 1) Identification } \\
\text { of other similarities } \\
\text { 2) Identification } \\
\text { of mutual interests: } \\
\text { excluded from the } \\
\text { present analysis (see } \\
\text { Table 1). }\end{array}$ & $\begin{array}{l}\text { Identification of } \\
\text { other similarities: } \\
\text { Refers to the attempt to } \\
\text { identify something the } \\
\text { FLE and customer have } \\
\text { in common, which can } \\
\text { be noted visually } \\
\text { without the need to ask, } \\
\text { e.g., the same age } \\
\text { range, same gender, } \\
\text { same type of physique, } \\
\text { among others. }\end{array}$ & $\begin{array}{l}\text { The FLE } \\
\text { identifies that the } \\
\text { customers prefer } \\
\text { to be served by } \\
\text { someone of the } \\
\text { same sex. }\end{array}$ & $\begin{array}{l}\text { Behavior with } \\
\text { nonverbal } \\
\text { emphasis }\end{array}$ & $\begin{array}{c}\text { Through } \\
\text { common gender }\end{array}$ \\
\hline \begin{tabular}{l}
\multicolumn{1}{c}{ Courteous } \\
behavior (Gremler \\
\& Gwinner, 2008): \\
Situations where \\
FLEs' behaviour \\
seems natural, \\
suggesting genuine
\end{tabular} & $\begin{array}{l}\text { Civility: Refers to } \\
\text { situations where the } \\
\text { FLE demonstrates } \\
\text { friendly, pleasant, } \\
\text { courteous or helpful } \\
\text { behavior. }\end{array}$ & $\begin{array}{l}\text { The FLE } \\
\text { interacts } \\
\text { respectfully, but } \\
\text { also warmly. }\end{array}$ & $\begin{array}{c}\text { Multifaceted } \\
\text { behavior, without } \\
\text { any specific } \\
\text { emphasis, } \\
\text { indicating a } \\
\text { complex } \\
\text { behavioral pattern }\end{array}$ & $\begin{array}{l}\text { Through warm } \\
\text { treatment }\end{array}$ \\
\hline
\end{tabular}


focus on the customer, instead of trying to sell. Formed by three subcategories: 1. Civility (broken down into two behaviors, as detailed in the third column)

2. Honesty: excluded from the present analysis (see Table 1).

3. Empathy: excluded from the present analysis (see Table 1)

Connecting behavior (Gremler \& Gwinner, 2008): Situations when FLEs explicitly try to develop a connection with the customer, by means of three

subcategories: 1. Friendly interaction

2. Humor: excluded from the present analysis (see Table 1)

3. Pleasant conversation: excluded from the present analysis (see Table 1)

Information sharing behavior (Gremler \&

Gwinner, 2008): Situations when FLEs try to share information with or gather information

\begin{tabular}{|c|c|c|c|}
\hline & $\begin{array}{l}\text { The FLE } \\
\text { interacts } \\
\text { respectfully, } \\
\text { maintaining } \\
\text { seriousness and } \\
\text { professional } \\
\text { distance. }\end{array}$ & & $\begin{array}{l}\text { Through } \\
\text { treatment with } \\
\text { professional } \\
\text { distance }\end{array}$ \\
\hline $\begin{array}{l}\text { Friendly } \\
\text { interaction: Refers to } \\
\text { pleasant and warm } \\
\text { behavior of FLEs } \\
\text { beyond that is } \\
\text { perceived as normal } \\
\text { when interacting with } \\
\text { customers. }\end{array}$ & $\begin{array}{l}\text { The FLE } \\
\text { converses with } \\
\text { customers, trying } \\
\text { to make them calm } \\
\text { about the } \\
\text { purchase, saying } \\
\text { that buying these } \\
\text { products is natural. }\end{array}$ & $\begin{array}{l}\text { Behavior with } \\
\text { verbal emphasis }\end{array}$ & $\begin{array}{l}\text { Through } \\
\text { reassurance }\end{array}$ \\
\hline $\begin{array}{l}\text { Transmitting } \\
\text { knowledge: Refers to } \\
\text { the sharing by the FLEs } \\
\text { of their own } \\
\text { experiences about a } \\
\text { specific subject. }\end{array}$ & $\begin{array}{c}\text { The FLE } \\
\text { shares information } \\
\text { about the products, } \\
\text { brands available } \\
\text { and corresponding } \\
\text { prices, but does } \\
\text { not offer an } \\
\text { opinion. }\end{array}$ & $\begin{array}{l}\text { Behavior with } \\
\text { verbal emphasis }\end{array}$ & $\begin{array}{r}\text { Through } \\
\text { information }\end{array}$ \\
\hline
\end{tabular}


$10^{\text {th }}$ International Conference on Modern Research in

MANAGEMENT, ECONOMICS and ACCOUNTING

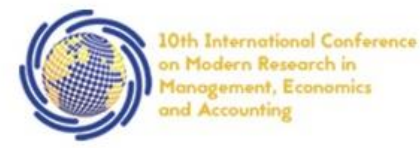

20-22 March, 2020

Berlin, GERMANY

\begin{tabular}{|c|c|c|c|c|}
\hline $\begin{array}{l}\text { from the customer, } \\
\text { to better understand } \\
\text { the needs, by means } \\
\text { of three } \\
\text { subcategories: } \\
\text { 1. Transmitting } \\
\text { knowledge } \\
\text { 2. Asking } \\
\text { questions } \\
\text { 3. Giving advice: } \\
\text { excluded from the } \\
\text { present analysis (see } \\
\text { Table 1) }\end{array}$ & $\begin{array}{l}\text { Asking questions: } \\
\text { Refers to FLEs who } \\
\text { pose specific questions } \\
\text { to determine what the } \\
\text { customer is really } \\
\text { looking for. }\end{array}$ & $\begin{array}{l}\text { The FLE poses } \\
\text { specific questions } \\
\text { to identify the type } \\
\text { of product or } \\
\text { medicine the } \\
\text { customer wants. }\end{array}$ & $\begin{array}{l}\text { Behavior with } \\
\text { verbal emphasis }\end{array}$ & $\begin{array}{l}\text { Through } \\
\text { questions }\end{array}$ \\
\hline $\begin{array}{l}\text { Imitation } \\
\text { behavior (Nickels, } \\
\text { Everett \& Klein, } \\
\text { 1983), also called } \\
\text { mirroring, an } \\
\text { approach often used } \\
\text { by neurolinguistics: } \\
\text { construction of } \\
\text { rapport is related to } \\
\text { the adaptation of } \\
\text { verbal and } \\
\text { nonverbal } \\
\text { communication of } \\
\text { the FLE to the } \\
\text { customer's style. }\end{array}$ & $\begin{array}{l}\text { Imitation behavior: } \\
\text { Refers to adaptation of } \\
\text { the verbal } \\
\text { communication of the } \\
\text { FLE to the style of the } \\
\text { customer (Nickels, } \\
\text { Everett \& Klein, 1983) }\end{array}$ & $\begin{array}{l}\text { The FLE refers } \\
\text { to the medicines } \\
\text { with the same } \\
\text { words used by the } \\
\text { customer. }\end{array}$ & $\begin{array}{l}\text { Behavior with } \\
\text { verbal emphasis }\end{array}$ & $\begin{array}{l}\text { Connection } \\
\text { with nominal } \\
\text { imitation }\end{array}$ \\
\hline
\end{tabular}

\subsection{Results of the Second CIT Application}

After content analysis of primary data from the second CIT conduction, it was necessary to add five more subcategories to those obtained on the first phase, in light of the practices mentioned by the FLEs as ways to soften the embarrassment of customers, by establishing rapport. The five new subcategories were: 1) Remove the products from the packages or deliver them very discreetly so that nobody (other customers, other FLEs, and especially the cashiers) can identify what the customer was buying; 2) Serve embarrassed customers as quickly as possible, because, according to FLEs who used this technique, what embarrassed customers most want is that situation to end; 3) Interact with the customer naturally, as if no embarrassment was perceived; 4) Serve customers discreetly in all details; and 5) Engage in small talk to relax the customer (see Table 3). 


\section{$10^{\text {th }}$ International Conference on Modern Research in MANAGEMENT, ECONOMICS and ACCOUNTING}

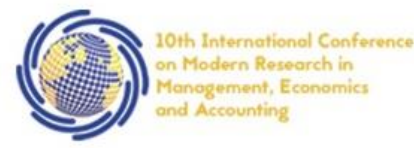

\section{0-22 March, 2020}

Berlin, GERMANY

Table 3: Explanation of the verbal and nonverbal behaviors included in multifaceted rapport behavior

\begin{tabular}{|c|c|c|}
\hline $\begin{array}{l}\text { Types of } \\
\text { multifaceted } \\
\text { rapport } \\
\text { behavior }\end{array}$ & $\begin{array}{l}\text { Types of verbal and } \\
\text { nonverbal behavior } \\
\text { included }\end{array}$ & $\begin{array}{l}\text { Examples of reports applicable to the behavior } \\
\text { obtained from the research subjects during application } \\
\text { of the CIT }\end{array}$ \\
\hline $\begin{array}{r}\text { Warm } \\
\text { treatment }\end{array}$ & $\begin{array}{l}\text { - Friendly tone of voice. } \\
\text { - Happy physiognomy. } \\
\text { - Position near the } \\
\text { customer. } \\
\text { - Supply of information } \\
\text { and suggestions. }\end{array}$ & $\begin{array}{l}\text { "... and in the final analysis, she's our customer, isn't } \\
\text { she? Because we embraced her and served her super well } \\
\text { and I showed this to her, saying "do you use it with or } \\
\text { without flaps, with or without perfume, cotton or dry } \\
\text { gauze?" So, after this, after talking with her, she felt super at } \\
\text { ease." (case of sale of a feminine sanitary napkin) }\end{array}$ \\
\hline $\begin{array}{l}\text { Treatment } \\
\text { with } \\
\text { professional } \\
\text { distance }\end{array}$ & $\begin{array}{l}\text { - } \text { Reserved tone of voice. } \\
\text { - Serious physiognomy. } \\
\text { - } \text { Sore distant position. } \\
\text { - Specific information. }\end{array}$ & $\begin{array}{l}\text { "...and he asked me "Is this the generic version of the } \\
\text { drug?", and I said "yes", and he said "No, it's not for me, } \\
\text { it's for my father", and I didn't continue the conversation, I } \\
\text { only stated the price, said it was the generic one and that } \\
\text { there was another company with a more accessible price, but } \\
\text { I did not pursue the subject very much." (case of sale of a } \\
\text { drug for erectile dysfunction) }\end{array}$ \\
\hline $\begin{array}{l}\text { Natural } \\
\text { service }\end{array}$ & $\begin{array}{l}\text { - Natural tone of voice. } \\
\text { - Physiognomy without } \\
\text { any expression other } \\
\text { than normal. } \\
\text { - Position that } \\
\text { accompanies the } \\
\text { demand of the customer. } \\
\text { - Pleasant conversation. }\end{array}$ & $\begin{array}{l}\text { "...we make the sale simpler, as if it were something } \\
\text { very common, routine, not demonstrating any expression } \\
\text { when the person asks. Here I don't show any surprise, or any } \\
\text { reaction." (case of a supposed sale of a product not } \\
\text { specified) }\end{array}$ \\
\hline $\begin{array}{l}\text { Discreet } \\
\text { service }\end{array}$ & $\begin{array}{l}\text { Tone of voice lower } \\
\text { than normal. } \\
\text { - Discreet physiognomy. } \\
\text { - Position near the } \\
\text { customer. } \\
\text { - Only necessary } \\
\text { information. }\end{array}$ & $\begin{array}{l}\text { "... I leave the customer at ease, say it is normal to ask this } \\
\text { question, or I'm discreet; he asks for the product and I get it } \\
\text { discreetly and put it in his hand or pass it to the cashier for } \\
\text { him, discreetly." (case of a supposed sale of a product not } \\
\text { specified) }\end{array}$ \\
\hline
\end{tabular}

The significant results are the final sub-categorization of the behaviors to establish rapport while serving customers in embarrassing situations, based on analysis of the 51 critical incidents reported in this study (see Table 4). 
Table 4 - Summary of the final sub-categorization of the behaviors to establish rapport in embarrassing situations in drugstores

\begin{tabular}{|c|c|c|c|}
\hline $\begin{array}{l}\text { Initial base in } \\
\text { the literature (see } \\
\text { 1st column of } \\
\text { Table 3) }\end{array}$ & $\begin{array}{l}\text { Behaviors of the FLF identified as } \\
\text { facilitators of rapport in embarrassing } \\
\text { situations }\end{array}$ & $\begin{array}{c}\text { Categories } \\
\text { created in this study } \\
\text { for establishment of } \\
\text { rapport in } \\
\text { embarrassing } \\
\text { situations with } \\
\text { emphasis on } \\
\text { behavior }\end{array}$ & $\begin{array}{l}\text { Subcategories } \\
\text { of rapport in } \\
\text { embarrassing } \\
\text { situations }\end{array}$ \\
\hline \multirow{4}{*}{$\begin{array}{c}\text { Category: } \\
\text { Uncommonly } \\
\text { attentive behavior/ } \\
\text { Subcategory: } \\
\text { Atypical actions }\end{array}$} & $\begin{array}{l}\text { Approaches the customer so the } \\
\text { interaction can be more discreet (e.g., } \\
\text { leaves the counter and goes to a corner of } \\
\text { the store). }\end{array}$ & \multirow{4}{*}{$\begin{array}{c}\text { Behavior with } \\
\text { nonverbal emphasis }\end{array}$} & Proxemics \\
\hline & $\begin{array}{l}\text { Adapts the voice to the same volume used } \\
\text { by the customer. }\end{array}$ & & Paralanguage \\
\hline & $\begin{array}{l}\text { Removes products from the package or } \\
\text { delivers them very discreetly so that it } \\
\text { cannot be identified. }\end{array}$ & & Camouflage \\
\hline & $\begin{array}{l}\text { Provides more agile service than is } \\
\text { normal so that the customer can make the } \\
\text { purchase as quickly as possible. }\end{array}$ & & Agility \\
\hline $\begin{array}{c}\text { Category: } \\
\text { Uncommonly } \\
\text { attentive behavior/ } \\
\text { Subcategory: } \\
\text { Personal recognition }\end{array}$ & $\begin{array}{l}\text { Establishes a certain distance, aware } \\
\text { that customers feel even more } \\
\text { embarrassed when recognized. Hence, } \\
\text { this category was used in its polar } \\
\text { opposite - non-recognition of the } \\
\text { customer on purpose, seeking anonymity. }\end{array}$ & $\begin{array}{c}\text { Behavior with } \\
\text { nonverbal emphasis }\end{array}$ & Omission \\
\hline $\begin{array}{l}\text { Category: Common } \\
\text { grounding behavior/ } \\
\text { Subcategory: } \\
\text { Identification of } \\
\text { other similarities }\end{array}$ & $\begin{array}{l}\text { Notes that the customer would prefer } \\
\text { to be served by someone of the same sex. }\end{array}$ & $\begin{array}{c}\text { Behavior with } \\
\text { nonverbal emphasis }\end{array}$ & Gender \\
\hline \multirow{3}{*}{$\begin{array}{c}\text { Category: } \\
\text { Courteous behavior/ } \\
\text { Subcategory; } \\
\text { Civility }\end{array}$} & $\begin{array}{l}\text { Acts respectfully, but friendly and } \\
\text { warmly. }\end{array}$ & \multirow{3}{*}{$\begin{array}{c}\text { Multifaceted } \\
\text { behavior (complex } \\
\text { pattern of behavior) }\end{array}$} & Warm treatment \\
\hline & $\begin{array}{l}\text { Acts respectfully, maintaining } \\
\text { seriousness and professional distance. }\end{array}$ & & $\begin{array}{l}\text { Treatment with } \\
\text { professional } \\
\text { distance }\end{array}$ \\
\hline & $\begin{array}{l}\text { Acts respectfully, maintaining a tone } \\
\text { of naturalness in the entire encounter. }\end{array}$ & & Natural service \\
\hline
\end{tabular}


$10^{\text {th }}$ International Conference on Modern Research in

MANAGEMENT, ECONOMICS and ACCOUNTING

\section{0-22 March, $2020 \quad$ Berlin, GERMANY}

\begin{tabular}{|c|c|c|c|}
\hline & $\begin{array}{l}\text { Acts respectfully, maintaining } \\
\text { discretion in all details. }\end{array}$ & & Discreet service \\
\hline \multirow{2}{*}{$\begin{array}{c}\text { Category: } \\
\text { Connecting } \\
\text { behavior/ } \\
\text { Subcategories: 1) } \\
\text { Friendly interaction } \\
\text { 2) Pleasant } \\
\text { conversation }\end{array}$} & $\begin{array}{l}\text { Talks with customers, trying to calm } \\
\text { them about the purchase, saying that } \\
\text { buying these products is natural. }\end{array}$ & \multirow[t]{2}{*}{$\begin{array}{l}\text { Behavior with } \\
\text { verbal emphasis }\end{array}$} & Reassurance \\
\hline & $\begin{array}{l}\text { Engages in small talk with the } \\
\text { customers, trying to put them more at } \\
\text { ease. }\end{array}$ & & Small talk \\
\hline \multirow{2}{*}{$\begin{array}{c}\text { Category: } \\
\text { Information sharing } \\
\text { behavior/ } \\
\text { Subcategories: } \\
\text { 1) Transmitting } \\
\text { knowledge } \\
\text { 2) Asking questions }\end{array}$} & $\begin{array}{l}\text { Shares information about products, } \\
\text { brands, availability and prices, but does } \\
\text { not give an opinion in this respect. }\end{array}$ & \multirow{3}{*}{$\begin{array}{l}\text { Behavior with } \\
\text { verbal emphasis }\end{array}$} & $\begin{array}{l}\text { Information } \\
\text { sharing }\end{array}$ \\
\hline & $\begin{array}{l}\text { Asks specific questions to identify the } \\
\text { type of product or medicine the customer } \\
\text { is looking for. }\end{array}$ & & Questioning \\
\hline $\begin{array}{l}\text { Category: Imitative } \\
\text { behavior }\end{array}$ & $\begin{array}{l}\text { Refers to the products in the same } \\
\text { terms the customers use. }\end{array}$ & & $\begin{array}{l}\text { Nominal } \\
\text { imitation }\end{array}$ \\
\hline
\end{tabular}

A schematic organization of this information shows 15 subcategories with nomenclature tailored for the theme rapport in embarrassing situations (see Table 5), with their respective associations with each of the three categoreis initially created and reported in the $4^{\text {th }}$ column of Table 2 .

Table 5 - Subcategories identified in the study, with nomenclature tailored to the theme of rapport in embarrassing situations, associated with each of the three categories initially created

\begin{tabular}{|c|l|}
\hline & 1) Paralanguage \\
Six subcategories associated with the category rapport & 2) Proxemics \\
behavior with nonverbal emphasis, with & 3) Camouflage \\
nomenclature partially inspired by Sundaram and & 4) Agility \\
Webster (2000) & 5) Omission \\
& 6) Common gender \\
\hline Five subcategories associated with the category & 7) Reassurance \\
rapport behavior com verbal emphasis & 9) Information sharing \\
& 10) Questioning \\
\hline Four subcategories associated with the category & 11) Nominal imitation \\
multifaceted rapport behavior, without specific & 13) Warm treatment \\
emphasis, in complex behavioral patterns & 14) Natural service \\
\hline
\end{tabular}




\title{
$10^{\text {th }}$ International Conference on Modern Research in MANAGEMENT, ECONOMICS and ACCOUNTING
}

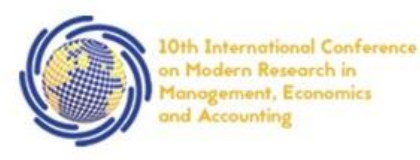

\author{
20-22 March, 2020
}

Berlin, GERMANY

\section{Conclusion}

According to literature, in some types of services customers prefer not to have relational consequences when interacting with service providers (Goodwin, 1996), but the examples refer to situations in which embarrassment is not involved. This is the case, for example, of fast food restaurants, where the goal is essentially speedy service, not interaction (Gremler \& Gwinner, 2000). One can imagine that the situation of an embarrassed customer is similar that of a fast food customer (although obviously stressed by the discomfort caused by embarrassment) since, in both cases, customers would perceive an attempt by the attendant to build a relationship as intrusive. Even when it is not necessary for customers to interact with someone while buying products that can cause some type of embarrassment, a simple look can be sufficient for them to abandon the purchase, upon noticing that their privacy is being invaded (Esmark, Noble \& Breazeale, 2017). And even if interaction with FLEs is not mandatory, in the case of potentially embarrassing products, the help of other customers can be seen as risky (Kim \& Yir, 2017).

Thus, the result of this study is not surprising: NVIC during face-to-face encounters with FLEs of drugstores can create rapport in situations when customers are bound to expose their privacy upon interacting with an FLE, as typically seen with drugs for erectile dysfunction and the morning-after pill. And this rapport could be identified in various ways, involving paralanguage, proxemics, camouflage, omission and common gender. On the other hand, the study revealed that customers' embarrassment can also be reduced by building rapport through verbal communication, identified in five subcategories: reassurance, small talk, information sharing, questioning and nominal imitation. These results contribute to the theory of rapport, which traditionally refers exclusively to behaviors separated into verbal and nonverbal. We identified a third category, able to blend the two behaviors in complex patterns of service, subverting the classic binary division of front-line communication as an instrument to display affect (Marinova, Singh \& Singh, 2018).

It should be stressed that this finding is not incompatible with the recommendation expressed in the literature regarding mutual exclusion, or one-dimensionality, in the coding of categories (Crowley \& Delfico, 1996). In other words, it does not fit in the undesired situation of having two or more categories without mutual exclusion, which often leads to the "wellintentioned practice of adding categories such as 'undecidable', 'none of the above', 'ambiguous' or 'applicable to two or more categories' to sets of categories with overlapping meanings" (Krippendorf, 2004, p. 132). The reason is that, in this research, we created a third principal category. This respected the requirement for application of one-dimensionality to any main category, while multidimensionality was recorded (as normally happens) in the overall codification table (Schreier, 2014). Proof of this argument, by the way, comes from the fact that the classification of the studied subjects' behaviors was performed respecting the separations between the three identified types of behaviors - verbal, non-verbal and multifaceted.

Being a qualitative study, this one carries some classic characteristics of this approach. For example, its results must take in consideration as a very important variable the level of awareness in which the communication occurs, overriding the space that may exist between what is desired to communicate and its interpretation (Hall, Horgan \& Murphy, 2018). Thus, not everything that was communicated might have been identified, and if it was, it is always possible that it was not fully and precisely understood. Another relevant point regarding this 


\section{$10^{\text {th }}$ International Conference on Modern Research in MANAGEMENT, ECONOMICS and ACCOUNTING}

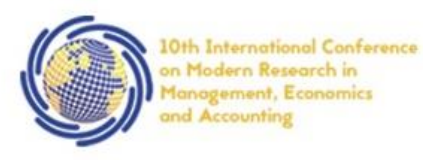

\section{0-22 March, $2020 \quad$ Berlin, GERMANY}

limitation is the possible existence of three types of research bias: 1) research context;2) investigation method; and 3) interviewer-interviewee relationship (Poupart, 2014).

Future studies can apply the same method in drugstores in a larger city, in search of alternative rapport-building behaviors subject to the need for faster service to customers. It would also be interesting to identify what types of rapport used by the FLEs are seen by customers as really able to lessen their embarrassment, as well as how those types of rapport, although well-intentioned by the FLE, wind up aggravating the embarrassment - i.e., contrast the information of this research with what the customers believe is ideal, or identify what kind of service they accept for not having an alternative, but would like to have been different. Finally, we suggest specifically identifying the types of language and postures that help or hinder any type of rapport.

\section{References}

Creswell, J. W. (2010). Projeto de pesquisa: métodos qualitativo, quantitativo e misto (3rd ed.). Porto Alegre: Artmed.

Crowley, B. P. \& Delfico, J. F. (1996). Content analysis: A methodology for structuring and analyzing written material. Retrieved May 18, 2018, from http://www.gao.gov/assets/80/76281.pdf

Esmark-Jones, C. L., Barney, C. \& Farmer, A. (2018). Appreciating Anonymity: An Exploration of Embarrassing Products and the Power of Blending In. Journal of Retailing, 94(2), 186-202. https://doi.org/10.1016/j.jretai.2018.01.001

Farmer, T., Robinson, K., Elliott, S. \& Eyles, J. (2006). Developing and implementing a triangulation protocol for qualitative health research. Qualitative Health Research, 16(3), p. 377-394

Flanagan, J. C. (1954). The critical incident technique. Psychological Bulletin, 51(4), p. 327358. https://doi.org/10.1037/h0061470

Goodwin, C. (1996). Communality as a Dimension of Service Relationships. Journal of Consumer Psychology, 5(4), p. 387-415.

Gremler, D. D. \& Gwinner, K. P. (2000). Customer-employee rapport in service relationships. Journal of Service Research, 3(1), 82-104. https://doi.org/10.1177/109467050031006

Gremler, D. D. \& Gwinner, K. P. (2008). Rapport-Building Behaviors Used by Retail Employees. Journal of Retailing, 84(3), 308-324. https://doi.org/10.1016/j.jretai.2008.07.001

Hall, E. T. (1963). A System for the Notation of Proxemic Behavior. American Anthropologist, 65(5), p. 1003-1026.

Hall, J. A., Coats, E. J. \& LeBeau, L. S. (2005). Nonverbal Behavior and the Vertical Dimension of Social Relations: A Meta-Analysis. Psychological Bulletin, 131(6), 898-924. https://doi.org/10.1037/0033-2909.131.6.898

Hall, J. A., Horgan, T. G. \& Murphy, N. A. (2018). Nonverbal communication. Annual Review of Psychology, 70(1), p. 1-24.

Human, L. J. \& Biesanz, J. C. (2011). Through the Looking Glass Clearly: Accuracy and Assumed Similarity in Well-Adjusted Individuals' First Impressions. Journal of Personality and Social Psychology, 100(2), 349-364. https://doi.org/10.1037/a0021850

Instituto Racine. (2018). Varejo Farmacêutico - Cursos. Retrieved March 27, 2018, from http://www.racine.com.br/setor/varejo-farmaceutico/

Isabella, G., Barros, L. S. G. \& Mazzon, J. A. (2015). A Influência do embarrassment do 


\section{$10^{\text {th }}$ International Conference on Modern Research in}

MANAGEMENT, ECONOMICS and ACCOUNTING

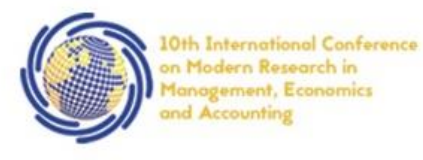

\section{0-22 March, 2020}

consumidor no processo de compra. RAC - Revista de Administração Contemporânea Anpad, 19(5), 626-648. https://doi.org/10.1590/1982-7849rac20151944

Keltner, D. \& Buswell, B. N. (1997). Embarrassment: Its Distinct Form and Appeasement Functions. Psychological Bulletin, 122(3), 250-270. https://doi.org/10.1037/00332909.122.3.250

Krippendorf, K. (2004) Content Analysis: an introduction to its methodology. Thousand Oaks: Sage Publications

Lim, E. A. C., Lee, Y. H. \& Foo, M.-D. (2017). Frontline employees' nonverbal cues in service encounters: a double-edged sword. Journal of the Academy of Marketing Science, 45(5), 657-676. https://doi.org/10.1007/s11747-016-0479-4

Marinova, D., Singh, S. \& Singh, J. (2018). Frontline Problem-Solving Effectiveness: A Dynamic Analysis of Verbal and Nonverbal Cues. Journal of Marketing Research, 55(April), p. 178-192.

McCracken, G. (1988). The long interview. Ontario: Sage Publications

Newman, R., Furnham, A., Weis, L., Gee, M., Cardos, R., Lay, A. \& McClelland, A. (2016). Non-Verbal Presence: How Changing Your Behaviour Can Increase Your Ratings for Persuasion , Leadership and Confidence. Psychology, (April), 488-499. https://doi.org/10.4236/psych.2016.74050

Nickels, W. G., Everett, R. F. \& Klein, R. (1983). Rapport Building for Salespeople: A Neuro-Linguistic Approach. The Journal of Personal Selling and Sales Management, 3(2), p. $1-7$.

Poupart, J. (2014). A entrevista de tipo qualitativo: considerações epistemológicas, teóricas e metodológicas. In A. Poupart, J.; Deslauriers, J.; Groulx, L.; Laperrière, A.; Mayer, R. Pires (Ed.), A pesquisa qualitativa. Enfoques epistemológicos e metodológicos. (4th ed.). Petrópolis: Editora Vozes.

Schreier, M. (2014). Qualitative Content Analysis. In: Flick, U. (ed.). The Sage Handbook of Qualitative Analysis. Thousand Oaks: Sage Publications,p.170-183

Sidtis, D. \& Kreiman, J. I. (2012). n the Beginning Was the Familiar Voice: Personally Familiar Voices in the Evolutionary and Contemporary Biology of Communication. Integrative Psychological and Behavioral Science, 46(2), p. 146-159.

Sundaram, D. S. \& Webster, C. (2000). The Role of Nonverbal Communication in Service Encounters. Journal of Services Marketing, 14(5), p. 378-391.

Willis, J. \& Todorov, A. (2006). Making up Your Mind after a 100-Ms Exposure to a Face. Psychological Science, 17(7), 592-598.

Wu, L. L., \& Mattila, A. (2013). Investigating consumer embarrassment in service interactions. International Journal of Hospitality Management, 33(1), 196-202. https://doi.org/10.1016/j.ijhm.2012.08.003 